\title{
Contestation of Islamic Radicalism in Online Media: A Study with Foucault's Theory on Power Relation
}

\author{
M Haramain ${ }^{1}$, Nurhikmah ${ }^{2}$, A B Juddah ${ }^{3}$, A S Rustan ${ }^{4}$ \\ IAIN Parepare, Jl. Amal Bakti No.8 Soreang, Parepare, Indonesia ${ }^{1,2,3,4}$ \\ \{haramain@iainpare.ac.id ${ }^{1}$, nurhikmah@iainpare.ac.id ${ }_{2}^{2}$ \\ abubakarjuddah@iainpare.ac.id ${ }^{3}$, ahmadsultrarustan@iainpare.ac.id $\left.^{4}\right\}$
}

\begin{abstract}
This article aims to study the patterns of Islamic discourses constructed by radical Islamic groups in social media. This article focuses on analyzing several Instagram accounts of the groups in shaping Islamic discourses. The discourses of Islamic radicalism were actually not a new idea, even now it has become one of the most talked phenomena. This study discusses the discourse of Islamic radicalism on social media, which is one of its missions is to promote the idea of formalizing Islamic sharia in Indonesia. This study uses descriptive qualitative research methods. It then uses Foucault's perspective on power relation theory to analyze these problems. The data collection techniques were observation and documentation techniques. The results showed that the forms of Islamic radicalism discourses on social media such as the invitation to avoid bid'ah, the campaign to implement Islamic law or Islamic state, Islamic Khilafah discourse that carries "anti-democracy", and a campaign to marginalize women's role in the public sphere. These issues are produced by radical Islamic groups through social media because these media are considered to be strategic and effective in campaigning their discourses as a means of ideological struggle. Fundamentalist Islamic groups are very keen to read the gap, they distinguish a change in the daily lifestyle of modern society which cannot be separated from the gadget. Therefore, they try to master and construct Islamic discourses in cyberspace with their point of view without considering to allow the differences of contextual understanding.
\end{abstract}

Keywords: Religious Discourses, Radicalism, Power Relation, Social Media

\section{Introduction}

Over the last few decades, the discussion of radicalism has been a quite popular and debatable topic in religious studies. Karen Armstrong has two objective reviews in looking at radicalism[1]. First, it must be perceived that the ideology of this movement is rooted in fear of avoiding secularism which is feared to eliminate them. Therefore, they formulate impeded doctrines. Second, awareness is should be raised that this movement is not an ancient thing that came from the past; they are a modern, innovative and modernizing movement. They read their religious foundations rationally.

Religious radicalism as a phenomenon in society extends with the massive support of social media. Urban people or urban communities tend to adopt a religion that puts culture and 
personal religious life on the opposite side. Religious life has tensions with local culture and traditions. Amid worldly activities and the spiritual scorched of urban communities, it turns out that many of the urban communities are eager or longing to study or learn about religious things again[2]. This is supported by the high accessibility of the internet and social media which are the biological children of modernity and diverse urban communities spend their time with the internet, hence many of today's society is very keen to study and search for a lot of religious literature through their closest media, the internet, and social media[3]. Because through the internet and social media, any information about anything can be accessed faster, anytime and anywhere. But regrettably, both the beginner or those who are willing to strengthen their religious knowledge then later exposed to the social media accounts and websites of radical Islamic groups, only because the account followers are many or the site's traffic is high.

Meanwhile, besides the urban society in general, who seeks much information and religious literature from the internet and social media, from age segmentation, the youth also tend to do the same in terms of obtaining information about religion. A national survey conducted by the Center for Islamic and Community Studies (PPIM) UIN SyarifHidayatullah Jakarta found that young people tend to get religious information more frequently via the internet and social media[4]. In the survey, students who sought religious information through the internet or social media were around $50.89 \%$. Then in general, millennial generation of young people also rely heavily on the internet, around $84.94 \%$ of students/university students have internet access and around $96.20 \%$ accessing the internet on cell phones and around $61.05 \%$ every day accessing the internet to find religious information.

Social media has become essential and been a lifestyle of modern society, a large number of users make social media an effective tool for groups, organizations, communities, and individuals to disseminate ideas, understandings, ideas, and ideologies.[5] For radical groups, the existence of social media opens up great opportunities for their activities and accelerates the spread of ideas and discourse they produce, because it can reach many people from diverse backgrounds.

Lorne Dawson and Douglas Cowan explain the difference between "religion online" and "online religion"[6]. Online religion is defined as information related to religion is on the internet, while online religion is the experience and practice of religion that is on the internet. In other words, the virtual space has become an epicenter in the search for modern human religion which then has an impact on offline religious rites.

A large number of social media users in Indonesia, causing social media the most effective tools for individuals, large groups and actors, both state actors and non-state actors as well as by Radical Islamic groups to spread their ideas, discourse and ideology as well as to develop their group networks while representing himself online[7]. By using social media such as Facebook, Instagram, Twitter, and YouTube, radical Islamic groups spread their doctrines in many ways, one of which is the use of terms or slogans with religious nuances and the form of religious symbols or slogans. This is in order to simplify and conveniently spread the message of radicalism through social media.[8], [9].

The born of new media, especially social media such as Facebook, Youtube, Twitter, Path, Line, Instagram, WhatsApp, and Telegram, also favorably strengthen the identity of radical Islamic groups and the discourse they brought. The discourse moves circulative on social media and other media such as news portals. Various forms of information can be disseminated quickly defeating conventional print and electronic media such as newspapers, magazines, bulletins, tabloids, television, radio, which are slowly declining in users. The presence of social media is massively well-used by radical Islamic groups. 
On social media, various forms of Islamic discourse from Islamic radicalism groups such as summons to wear Hijrah customs[10], [11], return to the Qur'an and Sunnah, or tagline Khilafah is the world resolutions are widely scattered. The author believes that this could erode the old discourse which is a picture of moderate and tolerant Islam. The dominance of discourse from the Radical group that we often encounter on social media was also supported by the attitude of the militant followers in their daily lives[12].

Thus, it becomes interesting for researchers to try to examine several social media accounts, especially on Instagram which is considered to produce Islamic radicalism discourse with the approach of discourse relations and the power of Michel Foucault. In relation to this research topic, the relation of dominant power and discourse production is used to dissect about how discourse about Islam is produced and disseminated by those who have power and subsequently the discourse becomes the dominant consumption in the religious field for the social media user community. The discourse formed by radical groups in social media will eventually display concepts or knowledge that are shaped and perpetuate truth claims about their version of religious understanding or what they have created and produced to the audience of social media consumers.

\section{Method}

The study is a qualitative research that tries to construct an analysis related to Islamic discourse produced by several selected Instagram. These accounts in social media are believed to have certain ideologies that make these accounts different from others. In this study, the author will conduct a text analysis of several posts related to Islamic discourse in the chosen Instagram account. This text analysis would be able to reveal the identity and ideology hidden in a text on social media.

In this article, radical Islam is used as a research material object while its formal object is the notion of the relationship of discourse and the power of Michel Foucault. While for this research the authors selected the Instagram social media accounts "Indonesia bertauhid official", "Mercusuar Umat", and "Indonesia Bertauhid Reborn". The account was chosen because the posts on the discussion of Islamic studies are so numerous and varied, and the number of followers or followers (other accounts) listening or responding to each post from the above accounts. Another reason is because the above accounts contained a production of Islamic discourse related to the theme of religious and state relations, the enactment of Islamic law as a positive law, a discourse on the establishment of the Islamic Khilafah, women and democracy in the Islamic view, and several other discourse that is directly related to the discourse of Islamic radicalism.

The data collection process is through several data sources that can be obtained by observation, and documentation. This study utilizes data in the form of a collection of texts, images, and videos that contain statements on social media, namely Instagram, which specifically contains the discourse of Islamic radicalism.

Furthermore, in the analysis of data, it will be elaborated related to text or posts in the form of videos and images from these Instagram accounts. Not only the text, images, or video as a device of communicating messages, but the meaning contained in the use of language and text will be explained first by the author. By understanding the meaning of the texts, videos, and pictures posted, it will be able to find about how Islamic discourse is formed in the Instagram account. Text descriptions will be seen as part of the language of social media in discussing their values. So, what is meant by the text at this stage is not only as a series of 
complementary sentences of uploaded images or videos, but also reveals the meaning and background that accompany it.

The next phase is when a text either in a speech transcript of a video or an image is displayed in a media, then the purpose of that will be seen. Subsequently, it will be noticed how the language and symbols in the post are used by radical group Instagram accounts to create a new ideology or discourse.

The last stage is the explanation of the analysis that provides answers and explanations of why the text, images, or videos from the Instagram post must be selected, then what substance will appear and produce what kind of substance. This stage will bring up an analysis that can distinguish what ideology contained in the Instagram account.

\section{Result and Discussion}

In the concept of discourse contestation, social media is seen as the construction agent of discourse or message, which defines reality according to its interests, then distributes it to the public. The media helps dominant or powerful groups to spread their ideas, control other groups, and form a consensus among community members. Media is not a free and neutral channel, but media is seen as an agent of social construction that defines reality with its views, biases, and alignments. Whatever discourse is produced by the media is the result of social construction that always involves certain views and values or ideologies. The media is also seen as a manifestation of the arena of ideological battles between groups in society.

In everyday life, the role of conventional media such as newspapers, magazines, radio, and television, or new media such as online news portals, and social media cannot be ignored in the process of constructing people's understanding of things. These media have an influence on the way people look at things. The construction of people's understanding of something is a very basic tool to find out why and how an individual or group of people perceive the world and all things in a certain way and what is the role of the media in shaping that view. In this study, the author will focus on the discussion of social media which is used as one of the media to deliver messages in the formation of Islamic discourse on social media, especially through selected Instagram accounts that the author will examine.

The process of constructing a discourse within a group emphasizes the role of the media as a method to build the discourse through the content broadcasted[13]. The characteristics of the new media that it brought made the internet can be seen as a social change engine capable of influencing people's beliefs and behavior[14]. Moreover, new media are also able to become cultural production media that reflect beliefs and behavior in the social environment. From the above thought, social media has indirectly become an important part of human life in shaping a perspective on something.

Therefore, it is not surprising that social media is full of contestation. In the context of this study, the media used by radical Islamic groups as a venue for contestation is Instagram. The content or discourse they produce is symbolically embedded through text and images that show the characteristics of the reality of the true teachings of Islam in the community in accordance with their group's understanding.

There are various interpretations of discourse, depending on the context and usage. There is no single agreement on the interpretation of discourse because the concept of discourse has a complex history and is used in different ways from various opinions[15]. With the existence of rapidly developing technology this time, creating discourse is not only limited to speech but also through writings or symbols and even images and videos. 
For Foucault, discourse is not understood as a series of words or propositions in the text, but something that produces something else (an idea, concept or effect)[16]. Discourse can be detected because it is systematically an idea, opinion, concept, and views of life formed in a particular context so that it affects the way of thinking and acting[17]. Studying discourse as a representation system is no longer limited to language. According to Foucault, besides constructing topics, defining and producing objects of knowledge, discourse also regulates how topics can be discussed continuously and also influences how ideas are converted into practice and used in social reality, this is because discourse has power and influence in a social context and structure our understanding of reality and ideas about our identity. Thus, on the other hand, discourse also has the ability to limit and exclude other ways, which are outside the prevailing discourse.

One of Foucault's most notable notion is the idea of the mutual relationship between knowledge and power. Implementation of power will continuously create knowledge and vice versa, ownership of knowledge will lead to power. This can provide an understanding that the role of knowledge is able to perpetuate the dominance of the superior group over other groups through the control of power by claiming the truth. Communities under the dominant group controlling the power will always be led to approve these truth claims in the form of scattered discourse, for example through social media.

Power is always articulated through knowledge, and knowledge always has a powerful effect. Running the power would always produce knowledge as the basis of its power. Power produces knowledge and not only because knowledge is useful for power. There is no knowledge without power and vice versa there is no power without knowledge. Certain discourses produce certain truths and knowledge that have a powerful effect. Power is not only the terminology of ownership or the state but also exists in small individual subjects. Power is the one who has the authority to determine the composition, relationships, and rules themselves such as socio-economic relations, family, sexuality, communication media and so on. Each power generates and produces its own truth through which the public is led to follow the established truth.

The concept of Foucault's discourse here is used to discover the discourse construction that emerges in the post uploaded by the selected Instagram account. Therefore, the contents of the account will be reviewed by the construction of discourse that underlies the construction of Islamic understanding through Instagram.

Of several forms of radicalism discourse that emerged from these Instagram accounts, it can be seen that the above accounts aim to construct and drive the public understanding of social media. This is where the power of discourse through language rules as the interpretation fabrication machine.

According to Foucault, the discourse has the ability to create knowledge while displaying a fear of the readers. By taking an example that the implementation of new rituals in a religion where the ritual is considered to have no origin (the argument) then those who do so will be rejected (not rewarded) and sinful. In fact, these rituals are often carried out by the community, such as tahlilan for the dead, mauludan, reading barzanji, etc[18]. The exclusion of other discourses that are considered different is done by making a classification of what is good and bad, which are acceptable and which are not acceptable. So that it discriminates against certain groups to weaken them. This is applied in order to communicate the discourse to the public.

Discourse related to this new ritual is employed by radical Islamic groups to produce a negative stigma to other Islamic groups who often practice this new ritual in their religious practice, in this case, addressed to the Traditionalist Islamic group or Nahdlatul Ulama. This new ritual is described as a bad religious practice, a source of conflict, leading to superstition, 
shirk, and so forth like what the Nahdlatul Ulama people have practiced. The use of tactics based on public fear is built systematically to raise panic and alertness so that people who carry out new religious rituals would then stop it. This pattern of power relations also occurs in other forms of Islamic radicalism discourse produced by these Instagram accounts.

Generally, radical groups frequently use verses of the Qur'an, hadiths, sayings of Ulama or other forms of religious power as a basis for the production of their discourse on social media[19][20]. They use the verses of the Qur'an, hadiths, sayings of Ulama posted in their account as a tool of legitimacy, expecting that after the public reads the post, the community would feel supervised and restricted in their movements when acting or carrying out religious rituals not in accordance with the posts they have read.

This is in agreement with Foucault's theory about Panopticons, which is the 'watchtower' that seems to continuously oversee people's movements. The term panopticons are given by Foucault to discipline the bodies of imprisoned prisoners. Foucault interpreted it as a general formula for power domination. Disciplinary social order (disciplinary social order) and community structuring based on discipline are important outlines in Foucault's theory. The mechanism of control through panopticons and the formation of obedient and disciplined individuals is a form of omnipresent power. Here power is no longer as simple as Gramsci's ideas of hegemony and dominance. Therefore, power operates through the construction of various knowledge in a particular discourse.

Foucault notices that the greatest impact of panopticons is to stimulate public awareness and views who believe the existence of the role of the power that takes place automatically without us being aware of it in our daily lives[21]. Thus, the concept of panopticons is characterized by the power of information by one party against another party. In the panopticons prison, the authority of all information is the guard, while the prisoner never knows the information. Therefore, prisoners are never subjected to communication.

In the context of this study, modern Muslim society is positioned as a prisoner overseen by guards in the form of a radical social media account that uses verses of the Qur'an, hadiths, sayings of Ulama or other forms of religious authority to control every action, way of worship as well as individual perceptions of Islamic discourse[22]. Like prisoners, in panoptic they think that they have to accommodate their behavior according to the wishes of the guards, social media users assume that they are always monitored and will be judged by social media audiences if they act on the disagreement of the dominant discourse. This is what was later known by Foucault as Panopticon, which are spaces where power relations run directly.

In a media such as social media, consideration of value or ideology in a post is usually determined by the background of religion and the values it espouses. When viewed from other types of posts from the above Instagram accounts, it can be seen obviously the sense of radicalism, although there are also some posts that discuss little things like the advice to get married at a young age. This also has implications for the use of the language exhibited from the above Instagram accounts which are directly inviting Muslims to return to the teachings of Islam purely based on the Qur'an and Sunnah. A language is a form of material ideology deliberately formed dialectically by an interest. From this understanding, it shows that there is indeed a tendency for the above Instagram accounts to favor the ideology or discourse of Islamic radicalism.

Hence, there is a power relationship that runs as described by Michel Foucault, that the production of Islamic radicalism discourse on Instagram or other social media is a powerful practice that does not operate repressively and intimidatingly, but works creatively and strategically by an ideology hidden and operates behind an Instagram account. and use social media as a tool for constructing the truth values of religion subjectively to social media users. 


\section{Conclusion}

Through social media, radical Islamic groups construct forms of Islamic radicalism discourse such as summons to avoid Bid'ah, campaigns to implement Islamic law or Islamic State and Islamic Khilafah discourse, shows the attitudes that are forbidden or "antidemocratic", and campaigns to marginalize the role of women in the realm of the public. This form of discourse was constructed and produced by radical Islamic groups through social media through pictures or lectures from their preachers. This is a strategic and effective step to campaign for their discourses as well as a tool to gain the support of audiences who are in fact a new generation of modern Indonesian Muslims. This generation is a Muslim community that in daily life is always connected with internet access and digital media and requires touch or propaganda content that is more interactive, effective and easily accessible.

Radical Islamic groups are very keen to take advantage of gaps by looking at changes in the lifestyle of modern humans that cannot be separated from gadgets, the internet, and social media. For that, they try to master and construct Islamic discourse on social media with the understanding they believe in. This strategy of mastering and constructing discourse through social media results from knowledge construction work that will effectively shape and perpetuate a Regime of Truth and henceforth be expected to become popular knowledge sourced from God and develop into norms or standard rules used by the community to determine what is considered true and not true. Thus, the power of Islamic radicalism discourse operates and shapes knowledge about Islamic discourse in individuals and society. The public is forced to only interpret texts as they are produced without critically reinterpreting them.

\section{References}

[1] K. Armstrong, Fields of blood: Religion and the history of violence. Random House, 2015.

[2] E. F. Nisa, "Social media and the birth of an Islamic social movement: ODOJ (One Day One Juz) in contemporary Indonesia," Indones. Malay World, vol. 46, no. 134, pp. 24-43, Jan. 2018, doi: 10.1080/13639811.2017.1416758.

[3] L. I. Cholidah, "RELASI MAYORITAS-MINORITAS DAN RADIKALISME DALAM KONSTRUKSI MEDIA ISLAM," Al'Adalah, vol. 20, no. 1, 2018.

[4] D. Maulana, "Situs-Situs Islam: Kontestasi Narasi Radikal dan Moderat," Jakarta, 2018.

[5] M. Haramain, "Dakwah Dalam Arus Globalisasi Media: Peluang Dan Tantangan," Komunida Media Komun. Dan Dakwah, vol. 7, no. 1, pp. 60-73, 2017, doi: 10.35905/komunida.v7i1.471.

[6] L. L. Dawson and D. E. Cowan, Religion online: Finding faith on the Internet. Psychology Press, 2004.

[7] N. Muthohirin, "Radikalisme Islam dan Pergerakannya di Media Sosial," Afkaruna Indones. Interdiscip. J. Islam. Stud., vol. 11, no. 2, pp. 240-259, 2015.

[8] M. Affan, "Ancaman dan Tantangan Muslim Indonesia Di Era Perang Proksi,” Anal. J. Stud. Keislam., vol. 18, no. 2, pp. 147-170, 2018.

[9] M. Affan, "The threat of IS proxy warfare on Indonesian Millennial Muslims," Indones. J. Islam Muslim Soc., vol. 8, no. 2, pp. 199-224, 2018.

[10] A. N. Sari and A. B. Mahadian, "PERILAKU KOMUNIKASI PELAKU HIJRAH," 
LINIMASA J. Ilmu Komun., vol. 1, no. 1, 2018.

[11] D. Prasanti and S. S. Indriani, "Interaksi Sosial Anggota Komunitas LET'S HIJRAH dalam Media Sosial Group LINE,” J. Messenger, vol. 9, no. 2, pp. 143-152, 2017.

[12] M. Haramain, "al-Wasathiyyah wa Atsaruha fi al-da'wah al-Islamiyyah: Dirasah Lugawiyyah Manhajiyyah,” Langkawi J. Assoc. Arab. English, vol. 2, no. 1, pp. 83$100,2016$.

[13] A. Sulfikar, "Swa-radikalisasi Melalui Media Sosial di Indonesia," J. Jurnalisa, vol. 4, no. 1, 2019.

[14] K.-Y. Kwahk and D.-H. Park, "Leveraging your knowledge to my performance: The impact of transactive memory capability on job performance in a social media environment," Comput. Human Behav., vol. 80, pp. 314-330, 2018.

[15] A. Wahid, "FUNDAMENTALISME DAN RADIKALISME ISLAM (Telaah Kritis tentang Eksistensinya Masa Kini)," Sulesana J. Wawasan Keislam., vol. 12, no. 1, pp. $61-75,2018$.

[16] C. Horrocks and Z. Jetvic, Introducing Foucault: A graphic guide. Icon Books, 2004.

[17] Eriyanto, Analisis Wacana: Pengantar Analisis Teks Media. Yogyakarta: LKiS, 2001.

[18] A. Z. Arifin, "Defending Traditions, Countering Intolerant Ideologies: Re-energizing the Role of Modin in Modern Java," Al-Jami'ah J. Islam. Stud., vol. 55, no. 2, pp. 265-292, 2017.

[19] G. Fealy and S. White, Expressing Islam: Religious life and politics in Indonesia. Institute of Southeast Asian Studies, 2008.

[20] M. Haramain, "DAKWAH DALAM ARUS GLOBALISASI MEDIA: PELUANG DAN TANTANGAN," KOMUNIDA MEDIA Komun. DAN DAKWAH, vol. 7, no. 1, pp. 60-73, 2017.

[21] M. Foucault, Discipline and punish: The birth of the prison. Vintage, 2012.

[22] J. Githens-Mazer, "The rhetoric and reality: radicalization and political discourse," Int. Polit. Sci. Rev., vol. 33, no. 5, pp. 556-567, 2012. 